\title{
Correction to: Ciliate Diversity From Aquatic Environments in the Brazilian Atlantic Forest as Revealed by High-Throughput DNA Sequencing
}

\author{
Noemi M. Fernandes ${ }^{1}$ (D) $\cdot$ Pedro H. Campello-Nunes ${ }^{1} \cdot$ Thiago S. Paiva $^{1} \cdot$ Carlos A. G. Soares $^{2} \cdot$ Inácio D. Silva-Neto $^{1}$ \\ Published online: 20 January 2021 \\ (C) Springer Science+Business Media, LLC, part of Springer Nature 2021
}

Correction to: Microbial Ecology

https://doi.org/10.1007/s00248-020-01612-8

The original article contained an error in the assignment of the author Carlos A. G. Soares name. The original version has been corrected.

The online version of the original article can be found at https://oi.org/ $10.1007 / \mathrm{s} 00248-020-01612-8$

Noemi M. Fernandes

noemi.mfernandes@gmail.com

1 Departamento de Zoologia, Universidade Federal do Rio de Janeiro, Rio de Janeiro 21941-617, Brazil

2 Departamento de Genética, Universidade Federal do Rio de Janeiro, Rio de Janeiro 21941-617, Brazil 